\title{
Private Military and Security Companies
}

\section{A Theoretical Overview}

\author{
Maria A. Nebolsina
}

\begin{abstract}
This article overviews the phenomenon of private military and security companies (PMSCs) through the prism of various theoretical concepts. The paper explores the heterogeneous nature of PMSCs, the reasons for their presentday increased activity, and interaction with state and non-state participants in global processes. The phenomenon manifests itself amid the change in the attitude towards traditional forms of violence, which allows states to partly outsource their security and law-enforcement functions. At the same time, some countries maintain their monopoly on violence and are even expanding the arsenal of mechanisms for consolidating their geopolitical influence through PMSCs. The study shows that PMSCs' activities in "weak" countries may impair the inviolability of their statehood. The article also discusses the possibility of democratic control of PMSCs' activities.
\end{abstract}

Keywords: non-state actors, private military and security companies (PMSCs), sovereignty, asymmetric conflicts, new types of war, privatization and outsourcing in the security field, democratic control, state monopoly on legitimate violence

Maria A. Nebolsina, PhD in Political Science

Center for Euro-Atlantic Security, Institute of International Studies, Moscow State Institute of International Relations (MGIMO), Russia.

Research Fellow

Researcher ID: E-4046-2012

Scopus Author ID: 24480923400

E-mail: nebolsinama@gmail.com

Address: 76 Vernadsky Prospect, 119454 Moscow, Russia

DOI: 10.31278/1810-6374-2019-17-2-76-106 
The growth of the global market of private security services and increased activity of PMSCs are taking place under the influence of various trends. First of all, the world has been witnessing a transformation of the power component of the system of international relations amid diversifying threats, which are becoming less predictable. Traditionally, the efforts of states aimed at implementing their geopolitical interests were largely based on military principles (Koppiters, Foushin and Apresyan, 2002). However, today large-scale interstate armed clashes (like WWI and WWII) are being replaced by "asymmetric," "low-intensive," "hybrid" wars involving such structures as PMSCs (Nye, 2014; Creveld, 2015; Kaldor, 2015; Kazantsev, 2013; Fenenko, 2015; Topychkanov, 2015).

The article aims to study PMSCs-an extensively developing factor of modern world politics-through the prism of different theoretical conceptions. As non-state actors, PMSCs are still a heterogeneous phenomenon characterized by both independency ("activism") and dependency on other actors ("instrumentalism"). The two-sided nature of this phenomenon raises a number of questions about the regulation, recognition and usefulness of PMSCs. In order to answer them, an in-depth theoretical analysis is required.

It is important to start with the definition of PMSCs. Currently, there are two applicable international mechanisms regarding private military and security companies: the Montreux Document (an agreement on pertinent international legal obligations and good practices for states related to operations of private military and security companies during an armed conflict) adopted in 2008, and the International Code of Conduct for Private Security Service Providers (ICoC) adopted in 2010. The summarized definition deriving from these documents is this: PMSCs are private business entities that provide military and/ or security services, either on their own or on behalf of other actors, irrespective of how they describe themselves. Military and security services include, in particular, armed guarding and protection of persons and objects, such as convoys, buildings and other places; maintenance and operation of weapon systems; prisoner detention; and advising/training of local forces and security personnel... or any 
other activity for which the Personnel of Companies are required to carry or operate a weapon in the performance of their duties (The ICoC, 2010; The Montreux Document, 2008).

The first methodological approach to studying PMSCs is institutional, which looks at PMSCs not only as commercial entities, but also as political institutions involved in the implementation of public interests. International organizations and states interacting with PMSCs in various circumstances legitimize their operations as a new and relatively independent international political institution, since these companies implement state interests through their own means and capabilities, thus becoming guides and intermediaries of the will of the state.

In the context of this study, the systemic approach is also used. It suggests a systematic analysis of the relationships and functions of state and non-state actors in ensuring the security of the state, society and the individual, and also their direct and reciprocal mutual influences.

In addition, for the purposes of this study the comparative-historical approach is used, which helps determine the stages of evolution and transformation of non-state private security and military activities, identify factors of PMSCs' growing role in international relations, and trace the increasing dependence of states on non-state actors, including PMSCs, in the historical perspective.

According to J. Nye, force is by no means obsolete, and no moral principles particularly deter terrorists and other non-state players on the global arena, but force is much more expensive for most states and it is much more difficult to apply nowadays (Nye, 2014). This is partly due to the commercialization of a significant part of what was traditionally public policy, including in the security sphere.

Active interaction with PMSCs began in the United States in the 1980s. U.S. strategic national interests were largely implemented through conflict behavior which, as many believe, is inherent in American politics (Sushentsov, 2014). Public criticism of the U.S. leadership concerning extensive personnel losses in the Vietnam and Korean Wars made Washington review its military behavior (Syrkhaev, 2012). Despite the necessity to cut the military budget and personnel 
of various law-enforcement agencies, the implementation of U.S. geopolitical interests still required additional resources and means that would not cause discontent of American society (Nebolsina, 2016). The U.S. needed "a mechanism for participating in regional conflicts without bearing the burdensome political responsibility... which opened the way to outsourcing military functions" (Syrkhaev, 2012).

\section{PMSCS IN THE CONTEXT OF VARIOUS PARADIGMS}

In the paradigm of political neorealism, private military and security companies are viewed as a new tool that replenishes diplomacy and strategy based on force as a means of protecting and promoting a country's geopolitical interests (Tsygankov, 2011). The concept of neorealism allows for any action if it is beneficial to the state (Pugachev, Solovyov, 2002). In this sense, PMSCs appear as "an important actor of national security and a social partner of the state" (Semenova, 2012). The use of PMSCs by states allows them not to jeopardize the lives of the regular army personnel and create an illusion of the absence of armed forces on the territory of other countries, while avoiding direct responsibility for the actions of non-regular military personnel. In a way, by replacing regular armed forces with contracted personnel a state can continue to build up weapons and maintain the power balance.

The argument that PMSCs are a new tool of the state's security policy is confirmed not only by U.S. experience, but also by that of the UK, which was the first to engage a PMSC in the early 1960s. The political background for the company's emergence was that in 1962 London refused to recognize the legitimacy of the new government in Yemen, which had come to power as a result of a coup d'état and the ensuing overthrow of the then ruling monarch. The United States and the USSR recognized the new regime, but the UK considered a plan to restore the legitimate power with the help of mercenaries, without involving national armed forces.

The founder of the UK special air forces, David Stirling, suggested that retired officers of the special air force service should be privately employed as instructors to train the monarch's supporters in operating weapons and communications and to provide them with medical 
aid. The 1967 events in Yemen led to the emergence of Watchguard International, the first PMSC. Thus, the operation in the Middle East marked the beginning of a new form of political confrontation between global powers that allowed them to realize their geopolitical interests without involving regular armed forces and avoiding overt interference in the domestic affairs of other countries. This also paved the way for new trends in the military-security sphere: education, preparation, and training of the armed forces personnel.

Involvement of PMSCs in conflicts is largely dictated by politically motivated reluctance of countries to perform certain functions by state structures. Such a leveling strategy allows a state to create the illusion of non-presence of regular armed forces personnel in the territory of other countries, while at the same time increasing its actual presence. That is, with a small contingent of regular armed forces, the U.S. seemingly realizes the declared democratic goals (fighting terrorism, restoring democratic values, changing dangerous regimes, providing security, freeing people from tyranny, etc.), while a "shadow" army of PMSCs fulfilling the mission and outnumbering the official contingent efficiently consolidates American influence in a particular region of the world (Nebolsina, 2016).

Following the neorealism paradigm, we can also mention Russia's experience of using Wagner and Patriot groups as PMSCs, although the example would not be quite accurate. Firstly, Russian PMSCs cannot be considered private military companies per se as Russian legislation prohibits any commercial military activity. Russian law permits licensed private security companies to perform the following functions: carry and use weapons in special cases, provide consulting and guarding services to individuals and companies, and protect objects and premises (Federal Law, 1992). Such companies are mostly engaged in protecting public and infrastructure premises in the territory of Russia. Private military companies that are active abroad, such as the RSB-Group and Moran Security Group, provide maritime and ground security services, convoying, training and consulting services or are contracted for demining operations. They have a complex legal structure that allows them to operate globally. While 
these groups of companies have Russian origins, their headquarters are registered abroad, making them international PMSCs.

Secondly, although the "soldiers of fortune" from Wagner and Patriot are known to move from one conflict to another (Ukraine, Libya, Syria, Central African Republic, and Venezuela), the obscurity of their functions, including mercenarism, likens them to illegal groups. Russia has been denying its involvement in any kind of mercenary activity abroad and casualties among Russian citizens participating in these groups. Wagner and Patriot that consist of "soldiers of fortune" rather than contractors can be compared with foreign mercenaries who once operated in the Congo crisis in the 1960s and in numerous African coup détats in the 1980s and 1990s. Finally, illegal use of mercenary groups even by a powerful state cannot replenish its arsenal of tools in the long term.

The practice of outsourcing the state's military functions to PMSCs, established by the UK and the U.S. in the second half of the 20th century, triggered the growth of commercial military security services to unprecedented levels. Today these two countries alone account for $75 \%$ of the global private military services market (with the U.S.' share amounting to about $50 \%$ and that of the UK, to about $25 \%$ ). In turn, the PMSCs that have sprung up in different countries over these decades are actively involved in the privatization of the state's security functions. That is, the processes of outsourcing and privatizing security go hand in hand. Of course, PMSCs can replace the state in terms of its force component only partially: national armies still retain control over large and most destructive weapon systems. At the same time, PMSCs have significant arsenals of light weapons, which for the most part are used in local and regional conflicts (Nye, 2014). In a recent interview former head of the notorious Blackwater company, Erik Prince, did not exclude the possibility of private military contractors replacing U.S. troops after their withdrawal from Syria (Griffing, 2019). However, the reaction of the Afghan authorities to Erik Prince' proposal was expectedly more than negative. Society rejects profitmaking by using irregular armed forces with precarious responsibility and refuses to turn into "kimberlite pipes" fueling crisis situations. 
Western countries' trend towards broader employment of military and security contractors can be attributed to two main reasons: the willingness to reduce casualties among the state military personnel, and to covertly promote their geopolitical interests. It is not without reason that the functions and the number of private military contractors engaged by U.S. intelligence services remain undisclosed. Should Erik Prince's proposal come true, there is a possibility that the information about the entire U.S. campaign in Afghanistan may be classified.

Outsourcing military functions is not a conventional practice in Russia. In its time, the Soviet Union broadly used its military advisors and specialists of all kinds for settling numerous regional conflicts abroad. Soviet military personnel were part of the state system that did not envisage delegation of any authority in any sphere, particularly in defense and security. After the collapse of the USSR in the 1990s, in line with Western liberal trends, business activity in Russia, including in the military sphere, increased for a short period of time. However, the distorted forms of privatization of security services in the 1990s posed a threat to the state's sovereignty. With invalid social and political institutions and the lack of solid legal regulation, characteristic of the transitional period, numerous armed groups comprised of unemployed former Soviet soldiers and militiamen overwhelmed Russia. The chaotic military activity of the 1990s triggered the emergence of separatist movements (specifically in Chechnya) and corporate raiding across the country. In the 2000s, the Russian authorities displayed strong will to take military activity under their control; currently they rely on departmental and nondepartmental security bodies. Russia's strong reluctance to outsource military functions and skepticism of private business in general put it into a conspiracy paradigm, hold back its competitive capability to operate globally, and preclude it from taking up the liberal trend, placing it at the opposite extreme to the military "outsourcing spree" proposed by Erik Prince.

Whereas from the neoliberal point of view the prevailing factor in international affairs is "the right of the strongest," the liberal concept recognizes the important role of international institutions, various 
entities and non-state actors (including PMSCs) in cooperation and policy implementation, and assumes that decision-making is influenced not only by state interests (Davydov, 2002). At the same time, the presence of numerous actors on the global arena creates disorder in international relations, leading to conflicts and crises that do not fit into the traditional realist model of the international system as a simple sum of states.

Although the priority areas for liberalism are cooperation and collective security, these phenomena cannot be considered separately from conflicts. The end of the Cold War was marked by the emergence of many local conflicts, which also increased the demand for PMSCs' services to restore stability and order at the local level, with the involvement of a small number of aircraft and technical equipment. PMSCs actively began to enter the markets of those states which required their assistance, and where the international community did not show any special interest, particularly in internal armed clashes. In situations where foreign forces did interfere in conflicts, international organizations themselves began to draw in PMSCs for peacekeeping and humanitarian operations (Gumedze, 2011).

For example, the UN engaged PMSCs in many of its missions in Africa (Gumedze, 2011). It is reported that UNICEF, WFP, UNHCR, UNDP and the UN Procurement Division are amongst the largest UN agencies and bodies contracting PMSCs (Bianchetti, 2016). In 2012 the UN Department of Safety and Security issued a UNSMS Security Policy Manual titled "Guidelines on the Use of Armed Security Services from Private Security Companies." The document refers only to those armed PMSCs that are contracted directly by the UN agencies as a "last resort" for "the static protection of personnel, premises and property of the United Nations and to provide mobile protection as outlined in this Statement of Works" (Guidelines, 2012). It should be noted that although a contracted company can be known as a PMC and be able to provide military services, for the purposes of the abovementioned UN tasks it will be involved in security activity only.

Not only the UN and its bodies directly outsource security functions, but so do its member-states involved in UN missions. The 
partnership programs of the member-states do not fall under UN regulation norms, that is, the process goes beyond the UN Manual and Guidelines. The UN cooperation with PMSCs under partnership programs generally covers three main areas: logistics and transport support of the mission (bases, airports, etc.), security and policing provision (demining, disarmament, etc.), and frontline forces support (training and instructing peacekeepers). These have been traditionally fulfilled by UN peacekeeping personnel but are now outsourced to third parties due to the lack of UN specialists. Nowadays virtually no UN operation which requires demining goes without employing PMSCs (Report of the Working Group, 2014; Langewiesche, 2014). For example, G4S actively assists the UN in demining activities. Previously, the South African company Denel cooperated with the UN in Somalia and Mozambique, providing mine protected vehicles and other equipment. According to the UN Working Group on the Use of Mercenaries as a Means of Violating Human Rights and Impeding the Exercise of the Right of Peoples to Self-Determination, as of May 2014, about 30 private military and security companies were involved in the organization's missions (Report of the Working Group, 2014). The extent of PMSCs' engagement in UN activities remains to be seen (Bianchetti, 2016).

The above-mentioned concept is complemented by the neoliberal model. Since the late 1970s, privatization of various spheres of life, the transfer of a multitude of functions at various levels to contractors, and public-private partnerships have spread globally (Nebolsina, 2014). Downsizing of armed forces across the world after the end of the Cold War and subsequent military missions in Afghanistan and Iraq not only made thousands of former military personnel seek employment in the ranks of private security agencies, but also provoked a shortage of military specialists at the state level. In the current situation of multiplying conflicts around the world and the outflow of skilled personnel from national military organizations to private entities, states and international organizations have to look for personnel in the PMSC market that has become very competitive due to protracted military operations in the Middle East (Brannen, 2015). 
In the early 2000s, mobilization of resources and means for the Global War on Terrorism (GWOT) led to a new phase in the development of the PMSC market. The demand for security services has increased manifold. In the course of military campaigns in Iraq and Afghanistan, the U.S. government transferred logistics functions (protection of military bases, transportation, convoy escorts, etc.) to PMSCs. The military campaigns in Syria and Iraq against ISIS have strengthened this trend. Also, a new giant has entered the market of private military and security services in recent years-China. Its buoyant economy and intention to protect commercial interests abroad have paved the way for the emergence of Chinese PMSCs. Simultaneously, we have been witnessing a transformation of the American and Chinese approaches towards violence (Volevodz, 2014).

\section{PMSCS AND THE CHANGE OF APPROACH TO VIOLENCE}

Since the establishment of the Westphalian system of world order, which in 1648 anchored the global political system for over 370 years now, the state has been considered the main actor in international affairs and military conflicts (Davydov, 2002). The force component of state power could not be delegated to any entity. This was the rule until a new phenomenon of modernity-PMSCs-emerged on the international scene. The outsourcing of power functions became part of a process that was initiated by the states themselves, creating demand for security (Nebolsina, 2014). This was also part of a more profound shift in the redistribution of state functions in general and in the security sphere in particular. The transformation of the attitude to violence has led to a revision of approaches to the state's exclusive monopoly on violence. This statement holds true only for the Westphalian countries and does not apply to former European colonies and dependent territories.

From the neoliberalist point of view, the modern state increasingly focuses on governance by involving private actors in the strategy of power. However, this statement is true only for states that are powerful in terms of resources and military means, states which do not perceive private security actors as a threat (that is, a force that can monopolize 
control and use its influence to assume certain governance functions while ignoring the authority of other actors).

The result of such cooperation between "strong" states and nonstate actors is the overlapping of the private security sector with that of the state. One of the most significant consequences of this is that the organization of power associated with a rigid hierarchy of state sovereignty is changing under the influence of the ongoing processes in the security field. For the neoliberal model it is important what means and capabilities a state has for governing the processes in the security field, with many actors incorporated in the security governance system.

The neoliberal model admits integration of additional forces into the security system, but one cannot say that the state arsenal is replenished with new capacities everywhere. That is, despite the fact that the diversity and the number of new non-state actors is increasing, they do not exist separately from states. Also, although not all states are fully able to control them, not all states lose their positions by partly transferring some of their security and law-enforcement functions. Transformational processes are not a simple substitution of governmental levers of power by non-state actors; rather they change the configuration of power in various spheres of activity (Abrahamsen and Williams, 2011). Commercial security services (PMSC) do not contest those provided by the state, and they do not act as a completely independent, autonomous sector within the state.

The global trend towards outsourcing security functions confirms the recent developments in China's private military and security services sector, which currently demonstrates a rapid worldwide growth. The shift from the "non-interference" approach to private security activity overseas started in 2010 when the Chinese government "passed legislation authorizing and regulating the establishment of commercial security firms" (Heath, 2018). The necessity was dictated by the need to protect the state's interests abroad. For example, the Chinese DeWe Security company, registered in Beijing in 2011, operates in Ethiopia, South Sudan, and the Central African Republic. Another Beijingbased company, Hua Xin Zhong An (HXZA), is engaged in maritime 
security services and is actually a security monopolist for two Chinese state shipping giants (Center for China Analysis and Strategy, no date). The increased attention to commercial security stems from the need to protect Chinese assets globally "without resorting to an imperialistic foreign policy" (Clover, 2017). Simultaneously, Beijing continues cooperating with foreign PMSCs. For example, Hong-Kong-registered Frontier Services Group (FSG), founded by Erik Prince, is contracted by Beijing for providing services within China and beyond (Security firm, 2019).

It is important to emphasize that the phenomenon of PMSCs is by no means homogeneous. In the case of the United States, the United Kingdom and China, they can be viewed as a tool for promoting state policies. In the case of international organizations, contracting PMSCs for peacekeeping missions is perceived as a way of cooperation. However, from the point of view of countries where such companies act under contracts in the interests of great powers, or entities assisting humanitarian and peacekeeping operations, PMSCs are represented as independent actors. As a result, the dividends from the balance of power are distributed between the participants in favor of militarily powerful states, and the PMSCs operating in Iraq, Syria, Afghanistan and various regions of Africa do not contribute to the realization of these countries' national interests at all (Kudryashova, 2012).

In the case of powerful countries, PMSCs for the most part do not pose a threat to national sovereignty, since in many ways they depend on the interests of states and the need to implement a political strategy with their help. A reduction in public spending and an increase in the number of new actors, including PMSCs, do not lead to a loss of control over ongoing processes. On the contrary, in poor countries, where economic liberalization has led to budget cuts, there has been a weakening of control and a loss of governing capacity. The growth in the number of PMSCs in Africa is partly due to the states' inability to provide security on their own.

Another example of PMSCs' heterogeneous nature is Latin American countries, where the market of security services dates back to the 1980s and 1990s. Weak social and government institutions and 
the lack of regulation put the Latin American security market in a gray or even illegal zone, much like in Africa. There are examples of private providers outnumbering state security forces, and cases of law-enforcement personnel working for such private entities. Local security companies are semi-legal groups with not quite professional personnel, rather than legal entities. They are mostly engaged with the extractive industry, providing armed and unarmed guarding, logistic services, escorts, protection of infrastructure, etc.

Today, PMSCs are able to become an alternative to the state power machine and even surpass the military departments of some states in professionalism, demonstrating a high degree of diversification of the services they provide (Abrahamsen and Williams, 2011). In cases where such organizations do not act in the interests of the state, but are engaged exclusively in business, the chances for PMSCs turning into a serious actor are increasing. In other words, "where the state's monopoly on power is undermined (as a result of inefficiency of the local government, civil actions, etc.)" (Savaskov and Safranchuk, 2012), PMSCs replace the institutions of power, thus undermining the sovereignty of "weak" states. In that case the sovereign powers of the state as a participant in the political process are delegated to other actors.

In contrast to the theories of neorealism, the concept of the balance of power, the theory of international regimes and others, which proceed from the idea that it is states that are a source of threat and only they can ensure stability at the national and international levels (Krahmann, 2005a), the concept of network security governance denies the exclusive claims of a sovereign state to this role (Abrahamsen and Williams, 2011). This concept explores the emergence of fragmented but overlapping networks, which form the basis for cooperation between state and non-state actors.

Prof. Dr. Elke Krahmann (2005b) points out that "in fragmented governance arrangements resources are dispersed among a range of public and private actors who have to coordinate their efforts in order to resolve common problems." He specifies that "governance implies an acceptance of the heterogeneous and sometimes conflicting nature 
of interests and seeks to ensure that each actor can pursue them as uninhibitedly as possible."

The network model rejects the priority of any dominant center in determining and regulating the activities of other actors in global processes. Within this framework governance is seen as a set of relationships inside the changing networks. Les Johnston proposes studying security governance through the prism of network nodes (links) as different areas of knowledge, capacities and resources that operate as independent governing structures (Abrahamsen and Williams, 2011). That is, the network concept allows decentralization of the state's positions in the sphere of security governance and does not imply its direct replacement by another independent actor. At the same time, the network model does not deny the dominant role of the state. As an institution enjoying the supremacy of power it is authorized to coerce and punish by legitimate judicial power. This capability of the state makes it a unique element of network governance.

The decentralized nature of the network "makes it possible for links to leave the network and connect to it at any time ... The significance of links does not stem from their specific features, but from their ability to distribute information. In this sense, the main links perform as switching nodes. Each link (actor) in the system has certain network power, that is, the ability to influence other participants' activities. However, this influence cannot be imposed on it, that is, the network power is different from the authority of the command" (Meteleva, 2008).

Such network behavior can be traced in the GWOT. When the campaign began in 2001, the PMSCs which accompanied the official armed forces became an important link in the network formed at the very start of the campaign. However, as the anti-terrorist operation moved from one region to another, the PMSCs, as a network link, followed the new armed operations. At the same time, they ceased to play an important role, leaving the network, when the operation was over in one place, and formed other links, entering other networks, in new antiterrorist operations.

Today, a similar situation can be observed in Syria, Iraq and other countries where antiterrorist operations against ISIS (McLeary, 2015) 
are being conducted. Military operations are organized as ad-hoc network strategies, which involve both the armed forces of various nation-states, for example, as participants in a coalition, and PMSCs which assist the main military forces. Remarkably, the PMSCs currently deployed to assist in Iraq are the same ones that participated in the military operation there a few years ago under contracts with the U.S. Department of Defense. These companies did not have to establish ties and engage in risk management from scratch. They are familiar with the terrain and know well the peculiarities of the situation inside the country, which greatly facilitates their activities.

The network strategy is also applicable to some countries in Asia and Africa, where states are often unable to provide security on their own. The network security governance system appears to be the most favorable alternative to other security mechanisms that work well in stable societies and states. In Africa, the privatization of the security sphere is proceeding actively. Traditionally, the African continent is perceived as an area which is slightly affected by globalization processes. At the same time, external assistance in ensuring security is in more demand here than anywhere else. This factor contributes to the intertwining of global and local processes in this region. In African countries, new forms of global (external) governance are emerging as international actors are increasingly getting involved in the governance system. The best-known actors, in addition to the PMSCs, are international organizations, financial institutions, donor countries, and NGOs. By consistent efforts in implementing their strategies for regional development, structural reforms and poverty reduction programs these actors have achieved enormous influence on the policies and decision-making in African countries.

Africa is an example of the reorganization of public-private relations, where global governance structures change due to the presence of private security actors, the diversified nature of global security manifests itself most vividly, and the "state-territory-power" triad that has long dominated international relations is breaking up (Abrahamsen and Williams, 2011). Perhaps today the African continent exemplifies "eroding" sovereignty, quasi-states and various 
forms of external governance, including PMSCs. On the other hand, is it possible to talk about statehood in the strict sense of the word with reference to Africa?

Thus, viewed from the network conception perspective, PMSCs play the role of a binding element in a network system that ensures its safety and security.

Another concept relevant for security issues is the securitization theory, developed by the Copenhagen school. This theory studies the context that affects the object and leads to its politicization, as well the process of assigning the status of a security threat to an object. Importantly, a new vision of the security problem does not automatically increase the list of threats, which include, in addition to military and security, non-military threats (Buzan, 2007). This can be seen in the example of macro-securitization of the United States in the fight against terrorism (Sushentsov, 2014).

By looking at terrorism as a threat to security and declaring war against it in the early 2000s, the United States attracted a huge amount of material and non-material resources, including by integrating PMSCs into the process. From 2000 to 2005, the budget allocated by the U.S. government for contracts increased from $\$ 203$ to $\$ 377$ billion, and more than doubled the number of contracts concluded on a noncompetitive basis: from $\$ 67$ to $\$ 145$ billion (Lilly S., 2007). Thus, securitization of the fight against terrorism leads to an increase in the number and value of contracts with PMSCs.

In late February 2015, several thousand American troops were sent to Iraq when a new operation was launched there. According to the Pentagon, by early 2015 about 6,300 contractors had been deployed in Iraq (Brannen, 2015). Considering that at the peak of the previous military campaign in Iraq the number of contractors exceeded 163,000, in the current mission their number will evidently increase. It is important to note that during the current campaign, the U.S. authorities have focused more on the operation's administrative support than on direct assistance to combat operations. For example, the Joint Command of the U.S. Strategic Armed Forces placed an advertisement in search of a private company capable of providing 
eight heavy-duty helicopters, each of which could carry at least 12 men and at least 2.2 tons of cargo (McLeary, 2015). Although it is well known that U.S. intelligence agencies engage PMSCs for tasks other than maintenance and advisory services, the true number of military contractors remains classified, it is never actually mentioned because "the military representative never has any estimates available" (Weisgerber, 2016; Zenko, 2016).

In June 2015, a U.S. company, SOS International (SOSi), the largest private contractor to support ground operations in Iraq, won an annual contract worth $\$ 700,000$. In the summer of 2015 , the U.S. government entered into two more contracts with the same company. According to one of them, a two-year contract worth $\$ 40$ million, the company was to ensure life support and operation of the military complex in Besmaya (Lee, 2015b); and according to the other one, worth $\$ 100$ million, it was to provide identical services on the territory of the Tajik military complex for three years (the contract was valid until the end of June 2018) (Lee, 2015a). Strictly speaking, SOSi is not a PMSC, nor does it fall under the Montreux Document or the ICoC, although it started providing security services in addition to "basic life support services" in 2015 (SOS International, 2015). This is how Allison Stanger, a professor of international politics and economics at Middlebury College, puts it: "In the era of contractor wars, there are many ways to avoid putting boots on the ground, while committing significant U.S. resources and actually being very much militarily involved" (Robson, 2014). In other words, in the context of the theory of securitization, the example demonstrates the diversification of private security means in order to meet the needs of counter-terrorist operations.

This trend can also be traced in Russia, which has securitized the problem of fighting terrorism (namely, ISIS) and, first, intensified the air military operation in Syria, and later launched large-scale joint Russian-Tajik military exercises (REGNUM, 2016).

On the one hand, in terms of this theory, the phenomenon of terrorism is being securitized. On the other hand, under the pretext of regulating international relations and combating terrorism with 
the help of norms and law, military operations are being intensified, the use of force is expanding to other spheres, and new opportunities for the use and implementation of new types of weapons and military equipment (Bogaturov, 2012) and new policy tools, such as PMSCs, are opening up.

\section{TRANSFORMATION OF THREATS AND NEW TYPES OF CONFLICTS}

The change in the nature of conflicts and wars can be explained within the framework of the concept of a new type of wars. To meet new challenges and threats, traditional wars are being replaced by nonclassical and non-state conflicts. Among the factors stimulating the emergence of new types of warfare are various forms of terrorism, including cyberterrorism, ramified networks of international extremist groups, problems of global inequality, depletion of natural resources, inability to control cash flows associated with financing of terrorist organizations around the world, etc.

As a result, today two types of conflict are most common. "On the one hand, there are intra-state conflicts for control over resources, the struggle for power, and economic dividends. On the other hand, there are asymmetric wars between major powers against rogue states or transnational threats" (Panova, 2005).

In the context of the study of the new type of conflicts "the process of globalization, which is increasing the number of poorly managed actors in international relations, can in some cases overcome the chaotic nature of the environment" (Davydov, 2002). This remark is important for the conclusion that the process of privatization of the security sphere and the formation of global security networks occur simultaneously with other global processes, in particular, with changes in the nature of modern conflicts and transformation of approaches to the use of violence in modern society.

Today, the state with its multifunctional and bulky military machine is more often opposed to groups of people whose arsenal is made up of mobile phones, the Internet and social networks. They have neither headquarters, nor front lines, nor bases. Despite the enormous military power, it is increasingly difficult for the state to cope with faceless but 
numerous enemies. However, whereas in the past the wars that could not be classified as interstate ones were recognized as riots, rebels or national liberation movements, piracy, etc., modern types of conflicts, whether "asymmetric," "hybrid," "informal," or "low-intensity," in fact have the features of "non-traditional" (in the sense of "non-state") wars of the past, when the state has to deal with a non-state opponent.

The assertion of Saskia Sassen, a Dutch researcher and sociology professor at the University of Chicago, that it is not so much globalization that contributes to partial limitation of state competence, as that many states themselves strengthen globalization, looks as the most accurate observation. From her point of view, many of the structures currently associated with globalization emerged as a result of the initiatives of the states and continue to develop within the changed national institutions, which make it possible to simplify the activities of such structures (Sassen, 2006).

Sassen believes that modern global structures include three key processes:

- the process of dismantling, during which previously considered exclusively state functions are increasingly concentrated in the hands of private actors;

- capacity building by private actors themselves, which allows them to operate at the international level;

- the process of re-installation, during which new actors and the opportunities they possess become part of global networks embedded in national processes, but operating at the international level (Sassen, 2006) ${ }^{1}$.

Importantly, the process of dismantling is not considered a sign of the nation-state's extinction. Rather, some elements of traditional state functions are undergoing changes and/or are being denationalized. The dismantling of some state structures affects other structures,

\footnotetext{
$1 \quad$ As a result of first "dismantling" and then re-installation in the security sphere, complex, multi-faceted institutional forms are created-global security networks within which various security actors interact, collaborate and compete for the right to create new and better security management practices.
} 
transforming the power relations between various organizations and institutions within the state (Sassen, 2006). In this sense, global processes are not an external force that is capable of undermining the nation-state's sovereignty and destroy the integrity of states. Globalization is a process that is embedded in the functioning and reorganization of institutions and power relations within the state.

Partial dismantling of the state's participation significantly contributed to the emergence of PMSCs with expanded powers and material resources, which were concentrated in the hands of such companies. Moreover, since the "legitimacy of most transnational actors is based on universal, regional, sectoral, particular utility" (Kuznetsov, 1999), the described process has led to the emergence of a conceptually new phenomenon: socially recognized forms of legitimation of activities in which interaction of such companies with any actor allows them to effectively operate in the security sphere. The state plays a very important role here, since it allows PMSCs to be integrated, while remaining autonomous, in the work of state structures, thereby legitimating and stimulating the companies' activities. The result of this process is the legislative regulation of PMSCs at the state, regional and international levels.

If we consider the growth of "security privatization" through the prism of dismantlement, re-installation and transformation of relations within power structures, it becomes obvious that the commercial sphere of security goes beyond traditional state institutions but does not at all abolish the monopoly of states for legitimized violence.

In the Russian academic community, there are scholars who speak about the erosion of sovereignty "due to the increasing permeability of borders and the weakening of the traditional functions of the state" (Tsygankov, 2005; Muntyan, 2006), as well as "due to the growing influence of new actors, with simultaneous weakening of the power of the state itself and its inability to function without the support of international cooperation institutions" (Tsygankov, 2005), which indicates that the trends that accompany the globalization process "lead to the weakening and change of the functions of nation-states" (Martynov, 1999). 
It is important to note that the understanding of statehood, which has formed in political science, is based on the thesis that the government's legitimate monopoly on violence and the means to achieve this monopoly are fixed once and for all, unshakable and do not change over time. However, even with the formation of modern states, the state's monopoly on violence has never been absolute. This assumption allows us to assert that the relationship between the state that can legitimately use violence and the understanding of statehood may change (Berndtsson, 2009). Outsourcing per se does not undermine the basics of state sovereignty, and PMSCs do not pose a threat to the inviolability of the state as a system. Outsourcing rather demonstrates a "challenge to the effectiveness of state control" (Balakhnin and Zhigzhitov, 2008).

Outsourcing of military-security activities should not lead to automatic delegation of related control and responsibility to private structures. However, such control does not necessarily belong exclusively to the government. It can be public. This statement is especially relevant for "weak" states or for conflict situations where the possibility of state control is either limited or non-existent (Berndtsson, 2009).

The changing nature of threats has triggered the emergence of the so-called Security Sector Reform (SSR) concept that has been widely discussed around the world in recent years. The issue of PMSCs' participation in this process remains unresolved, although these structures are included in the security system. Often, when it comes to projects and proposals relating to the reform of the public security sector, they are simply ignored (Gumedze, 2008).

Why is the inclusion of non-state actors in the reconstruction of the security sector important? As some Russian authors note, "in democratic countries, control over a military organization and military policy rests primarily on three pillars. Firstly, it is the control of legislative power over executive power, including its lawenforcement agencies," as well as the participation of legislators in military policy and military construction. Secondly, the basis of civil control is the institution of civilian defense ministers. And, thirdly, it 
is the openness of information, the access of scientific centers, press and public organizations to information about the vital activity of the armed forces and other law-enforcement agencies, 'replenishing' the legislative and executive authorities with civil society" (Arbatov, 2002).

In democratic societies, a nation-state, which exercises control over the use of force, holds direct and indirect consultations with society before resorting to means of violence (Fedorov, 2002). But if the state monopoly on the use of force is privatized by other structures, there is a possibility that the ban on the use of force would be overcome by other means. Then the participation of civil society in the dialogue with the state is ruled out, and the functions of public control are lost (Mandel, 2002).

On the one hand, the participation of PMSCs in ensuring security simplifies the process, removes the need to form and send military units to carry out tasks outside the country, and speeds up coordination and consultation procedures. On the other hand, mechanisms of democratic control, including that by civil society, are excluded from this process. Also, without a clear legal status, such security structures as PMSCs "that do not play a legitimate and democratically accountable role in providing security for citizens, are not only unable to prevent the emergence of conflicts, but they themselves can be a source of violence" (Born and Fluri, 2003; Lilly, Luckham and Von Tangen Page, 2002).

Speaking about the security system, it is important to understand that "not only is the object of democratic control expanding ... but the procedures, functions ... and some purposes of control are changing ... These are the tasks of including military organization in all of its various manifestations in the democratic structure itself" (Nikitin, 2002). Therefore, such a phenomenon as PMSCs should be given special attention in the context of reforming the security sector in order to determine their place in this sphere, assign a political status to them, and make them an object of democratic control.

Today private military security services are an actively developing and dynamic business with a multibillion-dollar turnover, a huge client network and a flexible structure that can compete, react quickly 
and successfully navigate the market. It is impossible to ignore such a force and not include it in the concept of security sector reform, just as it is impossible not to give it a universally recognized status and not to develop mechanisms of public control over these activities.

It is important to understand that democratic control over PMSCs' activities should be exercised in several ways. Firstly, the goals of companies' activities should be monitored, which implies oversight of the functions prescribed in PMSCs' contracts. Secondly, it is extremely important to assess the financing of PMSC contracts, that is, the financing party must clearly understand the assumed responsibility for proper use of funds by the PMSC (to avoid their misuse or fraud). Thirdly, control should address the issue of regulation for the compliance of PMSCs' activities with generally accepted norms regulating the operation of such companies, as well as transparency regarding the question of who they report to (Berndtsson, 2009).

As can be seen from this study, private military and security companies are a new, multifaceted and flexible element in the modern system of international relations. One of their significant features is that, being contracted by various clients (from state structures and international organizations to businesses, NGOs and individuals), PMSCs have a dual nature: they are "instrumental" in the hands of "strong" states, when acting as a continuation of the latter's policies, and independent in the eyes of "weak" states, when substituting for part of the functions of the state or international organizations.

Today, PMSCs provide transport and logistical support to U.S. forces in overseas campaigns and help the local authorities ensure order in African countries. They are included in UN missions for the protection of personnel, disposal of explosives, and restoration of the armed forces of "weak" countries (Gumedze, 2011). Representatives of these companies advise top officials and train military personnel around the world. PMSCs are involved in the protection of diplomatic representations and mineral deposits, decipher information recorded with the help of drones (Brannen, 2015), and perform law-enforcement 
functions, restoring public order in some countries (Buzatu, 2008). The situations in which private military and security companies operate are not confined to conflict zones only, but also include post-conflict and peaceful territories.

However, what for some states is implementation of their own interests (PMSCs instrumentalism), for others is interference in internal affairs (PMSCs activism). Importantly, in both cases such security functions are concentrated in the hands of PMSCs, while previously they were performed only by the states themselves. These factors underscore the importance of creating a special mechanism for regulating PMSCs' activities that would take into account the specifics of this type of business.

It is crucial to identify functions that under no circumstances should be transferred to third parties. Since in each country the list of inalienable state functions in the security sphere will differ, the optimal measure for today would be the legislative fixation of the impossibility of delegating such activities as storage, delivery and escort of WMD and the means of their delivery.

This measure will help reduce tensions associated with the potential threat that PMSCs may pose to the state's sovereignty and monopoly on the legitimate use of violence. This is also important because the status of PMSCs in international law has not yet been determined. Although PMSCs are partly legitimatized by the very fact that the actions of states determining the trends in international relations "can become a norm if fixed by a chain of precedents" (Buzan B., 2007), as well as by PMSCs' involvement in cooperation with international organizations (Singer, 2007), undue attention to such a sensitive issue as WMD should not become a threat to the entire world.

Military missions and peacekeeping and humanitarian operations in the world will continue, while private security services will take different forms to meet new challenges and needs. So, the PMSC issue will remain on the international agenda. Consequently, discussions on possible forms of regulation and legitimization of PMSCs' activities will continue, thereby affecting the development of international law. 


\section{References}

Abrahamsen, R. and Williams, M.C., 2011. Security beyond the state: private security in international politics. Cambridge University Press, $272 \mathrm{p}$.

Arbatov, A.G., 2002. Parlamentskiī kontrol' nad voennoī organizatsieī i politikoī Rossiīskoī Federatsii [Parliamentary control over the RF military organization and Russian policy]. In: Nikitin A.I., (ed.) Demokraticheskī kontrol' nad voennō sferoi $v$ Rossii $i$ stranah SNG [Democratic control over the military sphere in Russia and the CIS]. Moscow: Eslan, pp. 12-21.

Balakhnin, I. and Zhigzhitov, S., 2008. Transformatsiya gosudarstvennogo suvereniteta i voprosy problemnoī gosudarstvennosti v usloviyah perehoda $\mathrm{k}$ informatsionnomu obshchestvu [Transformation of state sovereignty and problems of statehood in the transition to information society]. In: Materialy konferentsii kafedry sravnitel'noī politologii "Gosudarstva i ih soperniki v mirovoi politike" [Materials of Comparative Politics' Department Conference: "States and their rivals in world politics"]. MGIMO, 19.11.2008. Available at: <http:// old.mgimo.ru/study/faculty/politcs/ksp/docs/34538/document34545.phtml> [Accessed 10 March 2019].

Berndtsson, J., 2009. The privatization of security and state control of force. Changes, challenges and the state of Iraq. Doctoral dissertation in Peace and Development Research School of Global Studies. University of Gothenburg. Available at: $<$ http://citeseerx.ist.psu.edu/viewdoc/download?doi=10.1.1.613.5 690\&rep=rep1\&type $=$ pdf $>$ [Accessed 10 March 2019].

Bianchetti, O., 2016. The role of private military security companies in the new generation of UN peacekeeping missions. Master Thesis in International Law. Available at: <https://serval.unil.ch/resource/serval:BIB_8B8A4D203B52. P001/REF> [Accessed 07 March 2019].

Bogaturov, A., 2012. Sovremennyī mezhdunarodnyī poryadok [Modern world order]. In: Ivanov, I.S., (ed.) Rossiya v global'nom mire: 2000-2011. Hrestomatiya v 6 tomah [Russia in a global world: 2000-2011. Six-volume textbook]. Moscow: Aspekt Press, Vol. 1, pp. 539-561.

Born, H. and Fluri P., 2003. Oversight and guidance: the relevance of parliamentary oversight for Security Sector Reform. Geneva Centre for the Democratic Control of Armed Forces (DCAF). Working paper, No. 114 [online]. Available at: <http://iskran.ru/cd_data/disk2/rr/021.pdf > [Accessed 11 March 2019]. 
Brannen, K., 2015. The company getting rich off the ISIS war. The Daily Beast, 02 August [online]. Available at: <http://www.thedailybeast.com/ articles/2015/08/02/the-company-getting-rich-off-of-the-isis-war.html> [Accessed 22 February 2019].

Buzan, B., 2007. People, states and fear: an agenda for international security studies in the post-Cold War era. Colchester: ECPR Press.

Buzatu, A.M., 2008. European practices of regulation of PMSCs and recommendations for regulation of PMSCs through international legal instruments. The Geneva Centre for the Democratic Control of Armed Forces $(D C A F)$. Available at: <http://psm.du.edu/media/documents/reports_and_ stats/think_tanks/dcaf_buzatu_european-practices.pdf> [Accessed 11 March 2019].

Center for China Analysis and Strategy. China: private security companies [online]. Available at: <https://ccasindia.org/newsdetails.php?nid=1877> [Accessed 07 March 2019].

Clover, C., 2017. Chinese private security companies go global, Financial Times, February 26.

Creveld, M. van., 2015. Transformatsiya voiny [Transformation of warfare]. Moscow: IRISEN, Sotsium, $320 \mathrm{p}$.

Davydov, Yu., 2002. Norma protiv sily. Problema miroregulirovaniya [Legal norm versus force. The problem of governance in the world order]. Moscow: Nauka, 287 p.

Federal Law, 1992. The Russian Federation Law N 2487-I of March 11, 1992 "About private detective and security activity in the Russian Federation". Available at: $<$ http://acquisition.ru/?page_id=1539> [Accessed 30 April 2019].

Fedorov, Yu.E., 2002. Grazhdanskiī kontrol' nad vooruzhennymi silami: mirovoī opyt i rossiīskie problemy [Civil Control over Military Forces: World Practice and Russian Problems]. Demokraticheskī kontrol' nad voennoī sferoī v Rossii i stranah SNG [Democratic Control over Military Sphere in Russia and CIS]. Nikitin A.I., ed. Moscow: "Eslan”, pp. 21-40.

Fenenko, A., 2015. Sovremennye konflikty - otrazhenie voin XVII-XVIII vekov [Modern conflicts: a reflection of wars of the 17th-18th centuries]. Narodny $\bar{\imath}$ korrespondent, 08 May 2015. Available at: <http://nk.org.ua/geopolitika/ sovremennyiekonfliktyi-otrajenie-voyn-xvii-xviii-vekov-5907> [Accessed 03 March 2019]. 
Griffing, A., 2019. Infamous private paramilitary firm Blackwater planning comeback. First stop: Syria. Haaretz, 21 January [online]. Available at: <https:// www.haaretz.com/middle-east-news/syria/.premium-blackwater-looks-totrump-for-a-comeback-in-syria-1.6850563> [Accessed 07 March 2019].

Gumedze, S., 2011. From market for force to market for peace. Private military and security companies in peacekeeping operations. Institute for Security Studies (ISS). Available at: <https://www.issafrica.org/uploads/Mono183.pdf> [Accessed 04 March 2019].

Gumedze S., 2008. Regulation of the private security sector in Africa. Policy Paper. Institute for Security Studies (ISS). Available at: <http://www.issafrica. org/uploads/PVTSECPOLPAPFEB09.PDF> [Accessed 22 February 2019].

Heath, T.R., 2018. China's pursuit of overseas security. Santa Monica: RAND Corporation. Available at: <https://www.rand.org/search.html?query=China\% E2\%80\%99s+pursuit+of+overseas+security> [Accessed 07 March 2019].

REGNUM, 2016 [no author]. Joint Russian-Tajik military exercises are on almost all along the Afghanistan border (In Russ.). REGNUM, 15 March [online]. Available at: <https://regnum.ru/news/2097607.html $>$ [Accessed 28 February 2019].

Kaldor, M., 2015. Novye i starye voiny: organizovannoe nasilie v global'nuyu epohu [New and old wars: organized violence in the global era]. Moscow: Izdatel'stvo Instituta Gaidara.

Kazantsev, A.A. and Sinegubov, A.L., 2013. Kontseptsiya operatsii "novogo tipa": opyt global'noī "voīny s terrorizmom" i operatsii v Irake [A concept of the "new type" operations: an experience of the Global War on Terrorism and the Iraqi operation]. Ezhegodnik IMI, No. 3-4, pp. 117-132.

Koppiters, B., Foushin, N. and Apresyan, R. (eds.) 2002. Nravstvennye ogranicheniya voiny: problemy i primery [Moral limits on war: problems and examples]. Moscow: Gardarika.

Krahmann, E., 2005a. New threats and new actors in international security. In: Krahmann, E. (ed.) From state to non-state actors: the emergence of security governance. New York: Palgrave Macmillan, pp. 3-19. Available at: <http:// www.palgrave.com/page/detail/new-threats-and-new-actors-ininternationalsecurity-ms-elke-krahmann/?K=9781403966971> [Accessed 10 March 2019]. 
Krahmann, E., 2005b. Security governance and networks: new theoretical perspectives in transatlantic security. Cambridge Review of International Affairs, 18 (1), pp. 15-30.

Kudryashova, Yu.S., 2012. Perspektivy uchastiya Turtsii v siriīskom konflikte [Perspectives for Turkey to join the Syrian conflict]. Ezhegodnik IMI, No. 1, pp. 263-269.

Kuznetsov, I.I., 1999. Transnatsional'nye otnosheniya $\mathrm{v}$ sisteme gosudarstv: partnerstvo ili novyi vitok sopernichestva? [Transnational relations in the system of states: partnership versus a new wave of competition?]. Kosmopolis, Al'manakh. Moscow: Polis, pp. 122-126.

Langewiesche, W., 2014. The chaos company. Available at: <http://www. vanityfair.com/news/business/2014/04/g4s-global-security-company> [Accessed 24 February 2019].

Lee, J., 2015a. More Iraq business for SOS Int'l. Iraq Business News, 3 July [online]. Available at: <http://www.iraq-businessnews.com/2015/07/03/ more-iraq-business-for-sos-intl/> [Accessed 26 February 2019].

Lee, J., 2015b. SOSi wins another Iraq order. Iraq Business News, 20 June [online]. Available at: <http://www.iraq-businessnews.com/2015/06/20/sosiwins-another-iraq-order/> [Accessed 26 February 2019].

Lilly, D., Luckham, R. and Von Tangen Page, M., 2002. A goal oriented approach to governance and security sector reform. Available at: $<\mathrm{http} / / /$ legacy. international-alert.org/sites/default/files/Goal_Oriented_Reform_Security_ Peacebuilding_EN_2002.pdf> [Accessed 11 March 2019].

Lilly, S., 2007. A return to competitive contacting. Congress needs to clean up the procurement process mess. Available at: $<$ https://cdn.americanprogress.org/ wp-content/uploads/issues/2007/05/pdf/procurement_paper.pdf> [Accessed 09 March 2019].

Mandel, R., 2002. Armies without states: the privatization of security. London: Lynne Rienner Publishers.

Martynov, V.A., 1999. Prognoz tendentsiī mirovogo ekonomicheskogo razvitiya. Glavnye faktory stanovleniya mirovogo poryadka [Outlook for the world economic development trends. Key aspects of the world order emergence]. Kosmopolis. Al'manakh. Moscow: Polis, pp. 12-17. 
McLeary, P., 2015. US looking for contractors to help in Iraq. DefenseNews, 9 March [online]. Available at: <http://www.defensenews.com/story/ defense/2015/03/09/us-private-contractor-iraq-isis/24654439/> [Accessed 09 March 2019].

Meteleva, E.R., 2008. Razrabotka teoretiko-metodologicheskih polozheniī setevogo upravleniya [The development of theoretical and methodological approaches to network governance]. Izvestiya IGEA, 3(59), pp. 69-72. Available at: $<$ http://izvestia.isea.ru/pdf.asp?id=4723 $>$ [Accessed 22 February 2019].

Muntyan, M., 2006. Osnovy teorii mezhdunarodnyh otnoshenizi. Uchebnoe posobie [Fundamentals of international relations theory. Textbook]. Moscow: MABiU. 164 p.

Nebolsina, M., 2014. Fenomen chastnyh voennyh i ohrannyh kompaniī: problemy legitimnosti [The phenomenon of private military and security companies: the problem of legitimacy]. Ezhegodnik IMI, No. 3-4, pp. 196-205.

Nebolsina, M.A., 2016. Regulirovanie deyatel'nosti chastnyh voenny $i$ ohrannyh kompanīi: sravnitel'nyī analiz politiki mezhdunarodnyh organizatsī $i$ mirovyh derzhav. [Regulation of private military and security companies: a comparative analysis of the policies of international organizations and world powers]. $\mathrm{PhD}$ Thesis. (Political Science)], Moscow.

Nikitin, A.I., 2002. Perestroika voenno-grazhdanskih otnosheniī v novyh nezavisimyh gosudarstvah [Reorganization of military-civilian relations in the new independent states]. In: Nikitin, A.I. (ed.) Demokraticheskī kontrol' nad voennoi sferoì $v$ Rossii i stranah SNG [Democratic control over the military sphere in Russia and the CIS]. Moscow: Eslan, pp. 6-11.

Nye, J. S. (Jr.), 2014. Budushchee vlasti [The future of power]. Moscow: AST.

Panova, V., 2005. Sovremennye zapadnye issledovaniya mezhdunarodnogo konflikta [Modern Western studies of an international conflict]. International Trends, Vol. 3, no. 2(8), pp. 53-65. Available at: <http://www.intertrends.ru/ seven/005.htm> [Accessed: 28 February 2019].

Pugachev, V. and Solovyov, A., 2002. Vvedenie v politologiyu. Uchebnik dlya studentov vuzov. [Introduction to political studies. Textbook for students]. Moscow: Aspekt Press, $477 \mathrm{p}$.

Report of the Working Group, 2014. Report of the Working Group on the Use of Mercenaries as a Means of Violating Human Rights and Impeding the Exercise of the Right of Peoples to Self-Determination Note by the Secretary- 
General. A/69/338. Available at: <http://psm. du.edu/media/documents/ international_regulation/united_nations/human_rights_council_and_ga/wg on_mercenaries/ reports_and_statements/a-69-338_russian.pdf> [Accessed 25 February 2019].

Robson, S., 2014. In place of "boots on the ground" US seeks contractors for Iraq. Stars and Stripes, September 7 [online]. Available at: $<$ https://www.stripes.com/ in-place-of-boots-on-the-ground-us-seeks-contractors-for-iraq-1.301798> [Accessed: 30 April 2019].

Sassen, S., 2006. Territory, authority, rights. Princeton University Press, 502 p.

Savaskov, P.V. and Safranchuk, I.A., 2012. Novye aspekty voennoi bezopasnosti: Piratstvo i chastnye voennye (silovye) kompanii. [New aspects of military security: piracy and private military (law-enforcement) companies]. In: Torkunov A.V. and Malgin, A.V. (eds.) Sovremennye mezhdunarodnye otnosheniya. Uchebnik [Modern International Relations. Textbook of MGIMO University]. Moscow: Aspekt Press, pp. 519-537.

AFP-JIJI, 2019. Security firm linked to Blackwater founder Erik Prince signs preliminary Xinjiang training deal. The Japan Times, 02 February [online]. Available at: <https://www.japantimes.co.jp/news/2019/02/02/asia-pacific/ security-firm-linked-blackwater-founder-erik-prince-signs-preliminaryxinjiang-training-deal/\#.XIZBDohKhPY> [Accessed 07 March 2019].

Semenova, L.A., 2012. Negosudarstvennaya sistema bezopasnosti kak novyī element sotsial'no-professional'noī struktury postsovetskoī Rossii [Non-state system of security as a new element of social and professional structure of post-Soviet Russia]. Materialy IV Ocherednogo Vserossiiskogo sotsiologicheskogo kongressa: "Sotsiologiya i obshchestvo: global'nye vyzovy i regional'noe razvitie" [Materials of the 4th Regular All-Russian Sociological Congress "Sociology and society: global challenges and regional development”]. Moscow: ROS, pp. 3216-3222. Available at: $<$ http://www.isras.ru/publ.html?id=2513 $>$ [Accessed 28 February 2019].

Singer, P.W. 2007. Corporate warriors: the rise of the privatized military industry. New York: Cornell University Press.

SOS International, 2015. SOS International to provide base life support to U.S. Army. 15 July. Available at: <http://www.sosi.com/news/press-releases/sosinternational-provide-base-life-support-us-army/> [Accessed: 30 April 2019].

Sushentsov, A., 2014. Ocherki politiki SShA v regional'nyh konfliktah 2000-kh godov [An essay on the U.S. policies in regional conflicts in 2000s]. Moscow, MGIMO University 
Syrkhaev, A., 2012. Privatizatsiya voiny v SShA [Privatization of the war in USA]. Istoriya gosudarstva i prava, No. 16, pp. 46-48.

The International Code of Conduct for Private Security Service Providers. 2010. Available at: <https://www.icoca.ch/en/the_icoc $>$ [Accessed 30 April 2019].

The Guidelines, 2012. The Guidelines on the Use of Armed Security Services from Private Security Companies. 08 November. Available at: https:// www.ohchr.org/Documents/Issues/Mercenaries/WG/StudyPMSC/ GuidelinesAnnexAStatementOfWork.pdf [Accessed 30 May 2019].

The Montreux Document, 2008. The Montreux Document on pertinent international legal obligations and good practices for states related to operations of private military and security companies during armed conflict. International Committee of the Red Cross. Available at: <file://C:/Users/ASUS/Downloads/ icrc_002_0996.pdf> [Accessed 30 April 2019].

Topychkanov, P., 2015. "Gibridnaya voīna" - nauchnyītermin ili propagandistskiī shtamp? ["Hybrid war" - a scientific term or a propaganda cliché?]. Carnegie Moscow Center, 15 July [online]. Available at: <http://carnegie.ru/2015/07/15/ ru-pub-60747> [Accessed 28 March 2019].

Tsygankov, P.A., 2011. (ed.) Mezhdunarodnye otnosheniya: teorii, konflikty, dvizheniya, organizatsii. Uchebnoe posobie [International relations: theories, conflicts, movements, organizations. Textbook]. Moscow: Al'fa-M, INFRA-M, Tsygankov, P., 2005. Mirovaya politika i ee soderzhanie [World politics and its content] International Trends, Vol. 3, No. 1(7), pp. 53-65. Available at: <http:// www.intertrends.ru/seventh/005.htm> [Accessed 10 March 2019].

Volevodz, A.G., 2014. Kriminalizatsiya mezhdunarodnogo terrorizma v ugolovnom prave [Criminalization of international terrorism under criminal law]. Mezhdunarodnoe ugolovnoe pravo i mezhdunarodnaya yustitsiya, No. 2, pp. 3-6.

Weisgerber, M., 2016. Back to Iraq: US military contractors return in droves. Defense One, 23 February [online]. Available at: <https://www.defenseone.com/ threats/2016/02/back-iraq-us-military-contractors-return-droves/126095/> [Accessed: 30 April 2019].

Zenko, M., 2016. Mercenaries are the silent majority of Obama's military. Foreign Policy, 18 May [online]. Available at: <https://foreignpolicy. com/2016/05/18/private-contractors-are-the-silent-majority-of-obamasmilitary-mercenaries-iraq-afghanistan/> [Accessed 30 April 2019]. 